\title{
Production of recombinant EMA-1 protein and its application for the diagnosis of Theileria equi using an enzyme immunoassay in horses from Sáo Paulo State, Brazil
}

Produção da proteína recombinante EMA-1 e sua aplicação para o diagnóstico baseado no imunoensaio enzimático de Theileria equi em equinos do Estado de São Paulo, Brasil

Cristiane Divan Baldani ${ }^{1}$; Eduardo Hilarioº ; Andréa Cristina Higa Nakaghi; Maria Célia Bertolini'; Rosangela Zacarias Machado ${ }^{3 *}$

${ }^{1}$ Departamento de Medicina e Cirurgia Veterinária, Instituto de Veterinária, Universidade Federal Rural do Rio de Janeiro - UFRRJ

${ }^{2}$ Department of Biochemistry, University of California-Riverside, Riverside, California, USA

${ }^{3}$ Departamento de Patologia Veterinária, Faculdade de Ciências Agrárias e Veterinárias, Universidade Estadual Paulista - UNESP

${ }^{4}$ Departamento de Bioquímica e Tecnologia Química, Universidade Estadual Paulista - UNESP

Receided November 26, 2010

Accepted January 18, 2011

\begin{abstract}
The erythrocytic-stage surface protein, Equi Merozoite Antigen 1 (EMA-1), is a major candidate for the development of a diagnostic antigen for equine piroplasmosis. In order to establish an effective diagnostic method for practical use, the gene encoding the entire EMA-1 of Theileria equi Jaboticabal strain was cloned and expressed in Escherichia coli as a histidine-tagged protein (His6-EMA1). The expressed EMA-1 reacted with specific antibodies in Western blot and had an apparent molecular mass of $34 \mathrm{kDa}$ which was largely consistent with its theoretical value. The nucleotide sequence of the EMA-1 gene of Jaboticabal strain was comparatively analyzed with other published sequences. The results indicated a high degree of homology with EMA-1 genes of all other strains isolated from various countries. The recombinant purified His6-EMA1 protein was tested in an enzyme-linked immunosorbent assay (ELISA) for the detection of antibodies anti-T. equi in horses. The ELISA clearly differentiated T. equi-infected from Babesia caballi-infected horse sera or normal horse sera. Field serum samples collected from horses in the State of São Paulo, Southeastern Brazil, were examined for the diagnosis of $T$. equi infection by ELISA. Of 170 samples analyzed, $95.88 \%(163 / 170)$ were positive for T. equi infection. These results suggest that the His6-EMA1 protein expressed in E. coli could be a reliable immunodiagnostic antigen for ELISA test and that T. equi infection is a serious concern in the State of São Paulo, Brazil.
\end{abstract}

Keywords: Theileria equi, diagnosis, EMA-1, ELISA.

\section{Resumo}

A proteína de superfície eritrocitária, Antígeno 1 do Merozoíta de Theileria equi (EMA-1), é um potencial candidato para o desenvolvimento de antígenos de valor diagnóstico para a piroplasmose equina. Com o objetivo de estabelecer um método de diagnóstico efetivo e prático, o gene EMA-1 da amostra Jaboticabal - SP de T. equi foi clonado e expresso em Escherichia coli contendo uma cauda de poli-histidina (His6-EMA1). O EMA-1 expresso reagiu com anticorpos específicos no Western blot e apresentou peso molecular aparente de $34 \mathrm{kDa}$, sendo altamente consistente com seu valor teórico. A sequência nucleotídica do gene $E M A-1$ da amostra Jaboticabal foi analisado comparativamente com outras sequências públicas, e os resultados indicam elevado grau de homologia com amostras de diversos países. A proteína recombinante purificada His6-EMA1 foi testada no ensaio imunoenzimático (ELISA) para a deteç̧áo de anticorpos anti-T. equi em equinos. O teste de ELISA diferenciou-se claramente entre soros de equinos infectados por T. equi, soros de animais infectados por Babesia caballi e soro normal de equino. Amostras de soros coletadas de equinos

\footnotetext{
*Corresponding author: Rosangela Zacarias Machado

Departamento de Patologia Veterinária, Faculdade de Ciências Agrárias e

Veterinárias, Universidade Estadual Paulista - UNESP,

Via de Acesso Prof. Dr. Paulo Donato Castellane, s/n,

CEP 14884-900, Jaboticabal - SP, Brazil;

e-mail: zacarias@fcav.unesp.br
} 
do Estado de São Paulo, sudeste do Brasil, foram examinadas para o diagnóstico da infecção por T. equi pelo ELISA. Das 170 amostras analisadas, 95,88\% (163/170) foram positivas para T. equi. Os resultados sugerem que a proteína His6-EMA1 expressa em E. coli pode ser um antígeno confiável para diagnóstico imunológico pelo teste de ELISA, e que T. equi merece grande atenção no Estado de Sáo Paulo.

Palavras-chave: Theileria equi, diagnóstico, EMA-1, ELISA.

\section{Introduction}

Equine piroplasmosis, also known as biliary fever, is a tickborne protozoal disease caused by two intraerythrocytic parasites, Theileria equi and Babesia caballi. This illness affects members of Equidae family (horses, mules, donkeys and zebras) and may occur in an acute, subacute or chronic form. The disease is generally characterized by fever, anemia, icterus, hepatosplenomegaly, intravascular hemolysis and petechial hemorrhages of mucous surfaces, and hemoglobinuria (SCHEIN, 1988).

This disease is widely distributed in tropical and subtropical areas worldwide where it causes significant economic loss to the horse industry (BRÜNING, 1996; DE WAAL, 1992; SCHEIN, 1988). International movement of horses into disease free-areas is allowed only if they have been tested negative for piroplasmosis through serological testing (UETI et al., 2005; BRÜNING, 1996; SCHEIN, 1988; TENTER; FRIEHOFF, 1986). In endemic countries, such as Brazil, the control of equine piroplasmosis is necessary to maintain the international market open to the horse industry.

In Brazil, the seroprevalence of T. equi and B. caballi is particularly high and recent studies have shown that it ranges from 75 to 90\% (HEIM et al., 2007; BALDANI et al., 2004; XUAN et al., 2001b). Despite the endemicity of equine babesiosis in the Western Hemisphere, the presence of tick vectors Rhipicephalus (Boophilus) microplus and Dermacentor nitens throughout the country points to the importance of equine piroplasmosis control and diagnosis in foreign animals (RIBEIRO et al., 1999; GUIMARĀES et al., 1998). Thus, with the V Military World Games in 2011 and the 2016 Olympic Games, both in the city of Rio de Janeiro, Southeastern Brazil, the number of imported horses from endemic areas will increase and therefore the detection of carrier status in these animals is necessary to prevent disease transmission. Indeed, equine piroplasmosis is the main difficulty for horse transportation to equestrian events or definitive exportation.

Since 1969 the complement fixation test (CFT) has been used as the certified assay for the detection of horses infected with T. equi (FRERICHS et al., 1969). However, several limitations of CFT including low sensitivity have been described and a number of different diagnostic methods have been proposed to improve the rate of detection of carrier horses (BRÜNING, 1996; TENTER; FRIEDHOFF, 1986; McGUIRE et al., 1971). The indirect fluorescent antibody test (IFAT) is commonly used for the diagnosis of T. equi infection, but as CFT, is generally limited by the detection range of antibodies and cross-reactivity (BRÜNING, 1996; SCHEIN, 1988). Besides the CFT and IFAT, enzyme-linked immunosorbent assays (ELISA) with T. equi lysate antigen has been used for the detection of antibodies to T. equi (BALDANI et al., 2004; WEILAND et al., 1986). Although good crude antigenic preparations from infected erythrocytes can be used in sensitive and specific ELISA, the test is hindered by a limited antigen supply (BALDANI et al., 2004). More recently, several ELISA tests have been developed with the use of recombinant antigens, demonstrating that it can be a useful test for the identification of chronically infected T. equi horses (JAFFER et al., 2010; SALIM et al., 2008; HUANG et al., 2003; CUNHA et al., 2002; HIRATA et al., 2002; XUAN et al., 2001a, b; TANAKA et al., 1999).

The molecular search for $T$. equi diagnostic antigens has focused on the identification of immunodominant proteins that are recognized by sera from horses infected with geographically distinct isolates. Equi merozoite antigen 1 (EMA-1) is a major surface protein of T. equi (KAPPMEYER et al., 1993) and is considered an important target for the development of an effective diagnostic reagent (CUNHA et al., 2002; XUAN et al., 2001a; KNOWLES et al., 1992). In the present study, we developed an ELISA method using the recombinant histidine-tagged EMA-1 protein based on a Brazilian T. equi strain and investigated its potential use for the diagnosis of $T$. equi.

\section{Material and Methods}

\section{Parasite}

The T. equi Jaboticabal strain (São Paulo State, Southeastern Brazil) was obtained in 1993 by Machado (BALDANI et al., 2004) from an 8-day-old foal and cryopreserved in liquid nitrogen as blood stability containing 10\% dimethyl sulfoxide.

\section{Cloning, expression and purification of recombinant EMA-1 antigen}

Erythrocytes infected by $T$. equi Jaboticabal strain were submitted to DNA extraction by a commercially available method (Puregene Kit, Gentra Systems Inc., USA). The full-length $E M A-1$ gene $(819 \mathrm{pb})$ sequence was amplified by PCR from genomic DNA using the primers EMA-1F (5'-GGAATTCATGATTTCCAAATCCTTTG-3') and EMA-1R (5'-GGAATTCTTAGTAAAATAGAGTAGAG-3'), which were designed based on the polynucleotide sequence of the protein EMA-1 from T. equi strain Pelotas (GenBank accession number AF255730). The underlined sequences correspond to the EcoRI site. The entire Open Read Frame (ORF) was subcloned into the pMOSBlue vector (Amersham Pharmacia Biotech) and the whole sequence was confirmed by DNA sequencing. The insert was then transferred to the pET28a expression vector (Novagen) using the same restriction sites. The correct plasmid construction 
pET28a-EMA1 and the control plasmid pET28a were used to transform Escherichia coli strain BL21 (DE3) competent cells, respectively. The production of the recombinant histidine-tagged protein (His6-EMA1) was first evaluated in a small scale $(50 \mathrm{~mL})$ assay using 2 YT medium containing $0.2 \%$ glucose and $30 \mu \mathrm{g} \cdot \mathrm{mL}^{-1}$ kanamycin. The production of His6-EMA1 (34.2 kDa) was

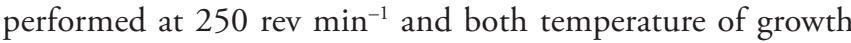
( 25 to $37^{\circ} \mathrm{C}$ ) and concentration of inductor ( 0.1 to $0.4 \mathrm{mM}$ IPTG) were assayed during induction. The production of the full-length His6-tagged polypeptide (58 amino acid residues, $6.3 \mathrm{kDa}$ ) was obtained at $250 \mathrm{rev} \mathrm{min}^{-1}, 37^{\circ} \mathrm{C}$ using $0.1 \mathrm{mM}$ IPTG. Protein expression was analyzed by sodium dodecyl sulfate-polyacrylamide gel electrophoresis 12\% (SDS-PAGE) and confirmed by Western blot using polyclonal anti-EMA-1 equine antibodies. Large-scale cultures were grown in 5-liter flasks containing $1.0 \mathrm{~L}$ of medium using the high expresser His6-EMA1 and polyhistidine tagged cell clones. The cells were cultivated at $30{ }^{\circ} \mathrm{C}$ until $\mathrm{OD}_{600}=0.6$ and protein production was induced with $0.2 \mathrm{mM}$ IPTG during 4 hours. Cells were harvested by centrifugation, resuspended in $0.1 \mathrm{~L}$ of lysis buffer containing $50 \mathrm{mM}$ Tris- $\mathrm{HCl}, \mathrm{pH} 9.0,500 \mathrm{mM}$ $\mathrm{NaCl}, 30 \mathrm{mM}$ imidazol, $1 \mathrm{mM}$ phenylmethylsulphonyl fluoride and $1 \mathrm{mM}$ benzamidine and lysed by sonication. Cell debris and nucleic acids were separated by centrifugation at 30,000 $\times \mathrm{g}$ for 30 minutes and the supernatant was applied in a nickel-affinity column in an Äkta Prime Purification System (Amersham Pharmacia Biotech, Uppsala, Sweden). Recombinant His6-EMA1 and His6tagged polypeptide were eluted in a linear elution gradient of 30-500 mM imidazol and their fractions were analyzed by SDSPAGE. Fractions containing the purified protein were pooled and dialyzed three times against $2 \mathrm{~L}$ of sodium bicarbonate-carbonated $0.05 \mathrm{M}$ buffer ( $\mathrm{pH}$ 9.6) at room temperature.

\section{Sera}

Horse serum samples used for the evaluation of ELISA with His6-EMA1 were as follow: 15 negative sera obtained from foals before they suckled colostrums; 15 serum samples that tested positive for $T$. equi parasites in blood smears and by IFAT; 3 sera from horses experimentally infected with $B$. caballi; 170 sera from horses of the Northeast region of the State of São Paulo.

\section{Immunization of mice with His6-EMA1}

Immunization of mice was performed as previously described by Machado et al. (1993). Ten micrograms of the protein His6EMA1 in Freund's complete adjuvant was intramuscularly injected into mice BALB/c. The same antigen in Freund's incomplete adjuvant was injected into mice on day 14 and again on day 28 . Sera from immunized mice were collected 10 days after the last immunization and evaluated by dot enzyme-linked immunosorbent assay (dot ELISA).

\section{ELISA}

ELISA was essentially carried out according to the method as previously described (BALDANI et al., 2004). The recombinant antigen His6-EMA1 and negative controls such as His6-tagged polypeptide and crude extract from E. coli strain BL21 (DE3) were coated to 96-well microplates (Nunclon ${ }^{\mathrm{TM}}$ Surface; Nunc, Denmark). Protein concentration was adjusted to 5, 10, 20 and $40 \mu \mathrm{g} \cdot \mathrm{mL}^{-1}$. Optimal dilutions of antigen and positive and negative sera were determined by checkerboard titrations. The immunological activity of each serum was calculated by determining the sample to positive serum ratio $(\mathrm{S} / \mathrm{P})$, considering positive and negative sera as reference, using the following equation:

$$
\frac{\left(\begin{array}{c}
\text { mean sample } \\
\text { absorbance }
\end{array}-\begin{array}{c}
\text { mean absorbance of } \\
\text { negative serum reference }
\end{array}\right)}{\left(\begin{array}{c}
\text { mean absorbance of } \\
\text { positive reference serum }
\end{array}-\begin{array}{c}
\text { mean absorbance of } \\
\text { negative serum reference }
\end{array}\right)}
$$

S/P values were grouped into ELISA levels (EL), which ranged from 0 (lowest level) to 9 (highest level). The discriminated absorbance value (cut-off) was determined as being two and a half times the mean absorbance value of the negative group, where readings equal to or grater than the cut-off value were considered positive. All tests were performed in duplicates.

\section{Western blot}

Sodium dodecyl sulfate polyacrylamide gel electrophoresis and Western blot analysis were performed as previously described (TOWBIN et al., 1979; LAEMMLI, 1970). Nitrocellulose membranes were assayed with positive $T$. equi and $B$. caballi control sera diluted at 1:100.

\section{Dot ELISA}

Dot ELISA was performed as previously described (MONTENEGRO-JAMES et al., 1990). Nitrocellulose membranes (pore size $0.22 \mu \mathrm{m}$ ) were cut into $5.0 \mathrm{~mm}$ disks and handled with forceps. Antigen in $10 \mu \mathrm{L}$ amounts ( $4 \mu \mathrm{g}$ of protein) was dotted on the dull side of the disks. Antigen was fixed onto the disks by drying for 30 minutes at $37^{\circ} \mathrm{C}$. Immunized mouse serum samples were diluted at 1:100. The development of blue-purple dots on disks when compared to negative serum and conjugate controls was considered an evidence of positivity.

\section{Results}

\section{Sequence analysis of EMA-1 gene from T. equi strain Jaboticabal}

The EMA-1 gene from T. equi strain Jaboticabal-SP was amplified by PCR and subcloned into pET28a expression vector. The full-length sequence was confirmed by DNA sequencing and the ORF encoded a protein of 272 residues of amino acids. Multiple sequence alignment was performed to evaluate the identity of EMA-1 from T. equi (GenBank accession no. DQ250541) with the same protein from different strains. There are more than 20 sequences of EMA-1 from different isolates deposited previously in the GenBank databank. All sequences are highly conserved, however the sequence of the protein EMA-1 from the 
T. equi strain Jaboticabal is identical with other three polypeptide sequences previously deposited. Moreover, this protein shows high identity $(99.3 \%)$ compared with the same protein from T. equi strain Pelotas (Figure 1), differing by two amino acids residues at positions 84 and 200 .

\section{Protein expression and purification}

Recombinant EMA-1 was expressed in soluble form (Figure 2) and the single-step purification by immobilized metal-affinity chromatography was sufficient to obtain high amounts of pure protein $\left(15 \mathrm{mg} . \mathrm{L}^{-1}\right)$. The relative molecular mass of the recombinant His6-EMA1 was $34 \mathrm{kDa}$ by SDS-PAGE analysis, largely consistent with its theoretical value (KNOWLES et al., 1997). Western blot analysis shows that His6-EMA1 strongly reacted with sera from T. equi-infected horses but not with sera from uninfected horses (Figure 3). Additionally, no reaction was seen with crude extract from E. coli or the His6-tagged polypeptide. Some extra bands were detected by the horse serum in recombinant lysates and may represent alternative transcription or translation of EMA-1 proteins, aggregation of EMA-1 products or degradation of expressed proteins.

\section{Immunogenicity of EMA-1}

To determine the immunogenicity of the EMA-1 gene expressed in E. coli, BALB/c mice were immunized and the reactivity of the antiserum was analyzed by Dot ELISA. The results demonstrate that anti-T. equi antibody produced in mice strongly reacted with recombinant His6-EMA1.

\section{Evaluation of ELISA with His6-EMA1}

To evaluate whether the His6-EMA1 expressed in E. coli can be used as a suitable antigen for the diagnosis of T. equi infection, particularly in Brazil, the purified His6-EMA1 was tested in an ELISA using positive and negative reference serum, as well as sera from horses experimentally infected with B. caballi. Checkerboard titrations showed an antigen concentration of $5 \mu \mathrm{g} \cdot \mathrm{mL}^{-1}$ in carbonate buffer, pH 9.6, as optimum. Serum samples were diluted at 1:100 and alkaline phosphatase conjugated anti-horse IgG (Sigma Chemical Co., USA) used at 1:30.000. The average absorbance of negative sera was $0.105 \pm 0.013$, resulting in a calculated cut-off value of 0.263 (EL 3 - Table 1). Absorbance values found with anti-B. caballi sera were lower $(0.161 \pm 0.017)$

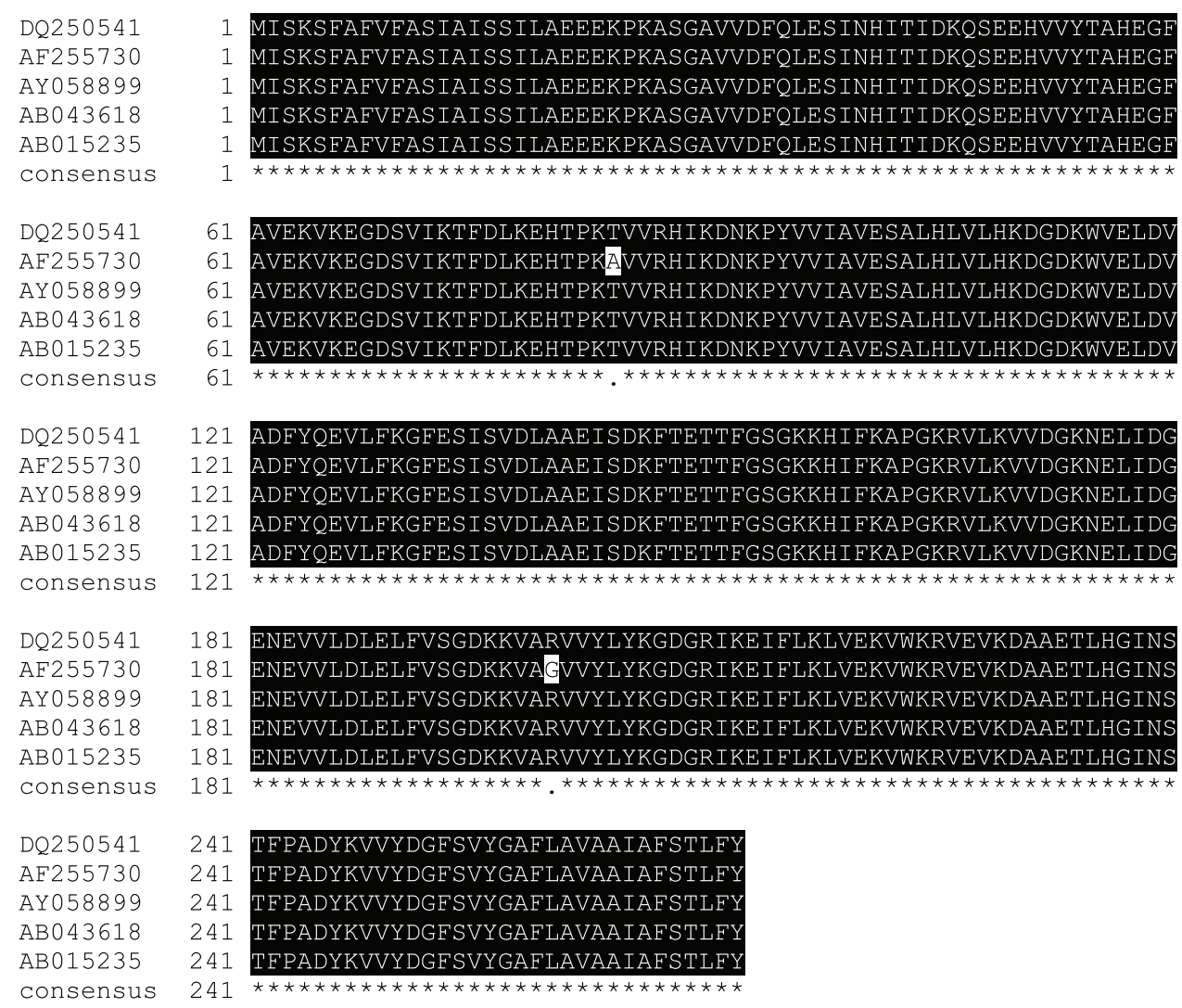

Figure 1. Multiple sequence alignment of amino acid sequences of EMA-1 proteins. The sequences correspond to the T. equi strain Jaboticabal, Pelotas, Brazil 2, USDA and Florida-JRA with GenBank accession no. DQ250541, AF255730, AY058899, AB043618, AB015235, respectively. Except for the protein EMA-1 from strain Pelotas that exhibits two amino acid changes into the polypeptide sequence (Thr84Ala and Arg200Gly), the sequence of EMA-1 from strain Jaboticabal is identical to the other strains. This figure was generated using BoxShade 3.21 (http://www.ch.embnet.org/software/BOX_form.html). Regions of amino acid identity are shown in black; non-conservative substitutions are shown in white. 


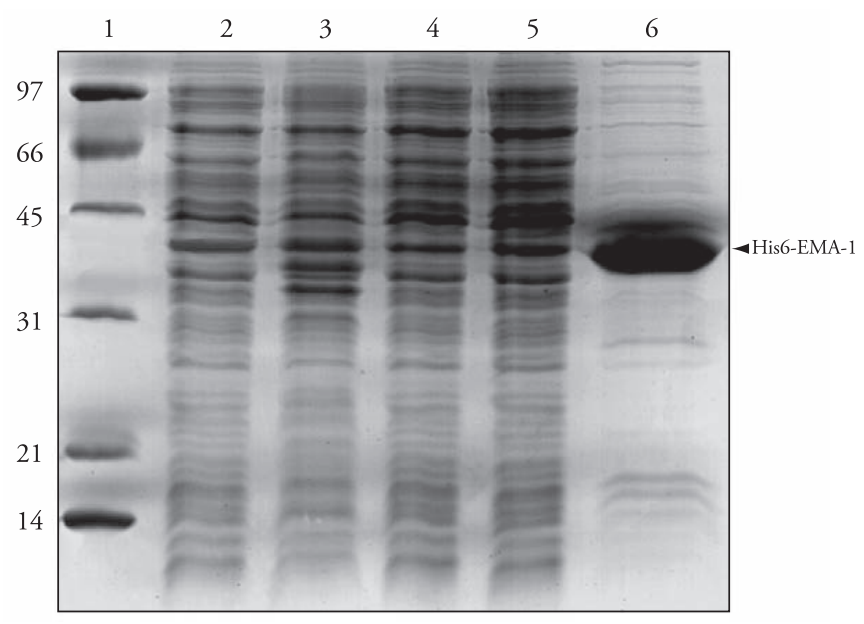

Figure 2. SDS-PAGE of protein samples from His6-EMA1 purification. (1), molecular weight markers (kDa) (Low Range, Bio-Rad); (2), crude extract; (3 and 4), supernatant and precipitate after centrifugation, respectively; (5), flow through and (6), His6-EMA1. The protein was fused to His6-tag at the $\mathrm{N}$-terminus. The cells were lysed in $50 \mathrm{mM}$ Tris- $\mathrm{HCl}, \mathrm{pH} 9.0$, containing $500 \mathrm{mM} \mathrm{NaCl}, 30 \mathrm{mM}$ imidazol, $1 \mathrm{mM}$ benzamidine and $1 \mathrm{mM}$ PMSF. The protein was purified by affinity chromatography in $5 \mathrm{~mL}$ HiTrap Chelating in an Äkta Prime Purification System (Amersham Pharmacia Biotech). His6-EMA1 was eluted in a linear gradient using 30-500 mM imidazol. The protein was dialyzed against $10 \mathrm{mM}$ Tris- $\mathrm{HCl}, \mathrm{pH} 9.0$, containing $10 \mathrm{mM} \mathrm{NaCl}$. Twenty-five micrograms of proteins were loaded in each well and the gel was stained with Coomassie Blue R250. The arrow indicates the full-length fusion protein with $34.2 \mathrm{kDa}$, based on the theoretical molecular weight.

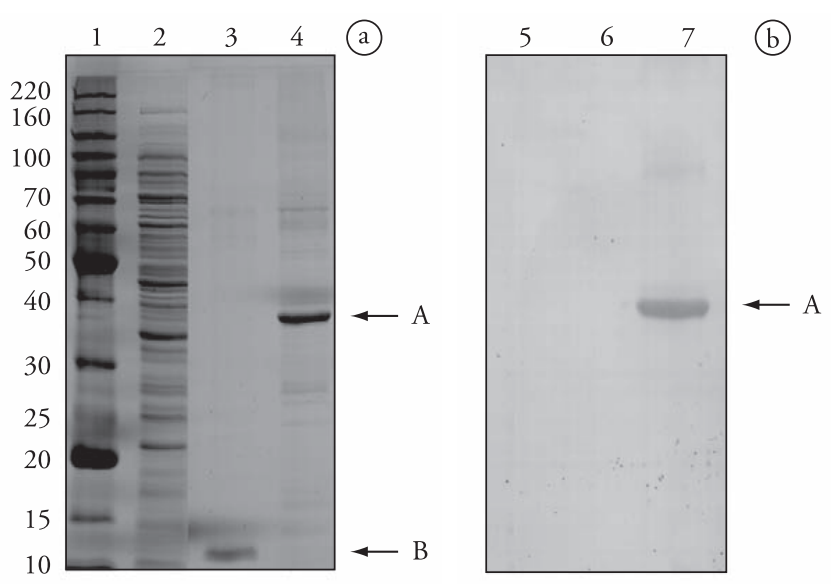

Figure 3. SDS-PAGE and Western immunoblotting of recombinant His6-EMA1. a) SDS-PAGE 12\%. 1) molecular weight markers (kDa) (Bench Mark Ladder, Invitrogen); 2) crude extract from E. coli strain BL21 (DE3) carrying the plasmid pET-28a without EMA1 gene subcloned (control) $(20 \mu \mathrm{g})$; 3) His6-tagged polypeptide tag $(5 \mu \mathrm{g})$; and 4) recombinant His6-EMA1 protein $(5 \mu \mathrm{g})$. b) Western immunoblotting. 5) crude extract of E. coli lysates; 6) His6-tagged polypeptide tag; and 7) His6-EMA1 were detected by the anti-EMA-1 polyclonal horse antibody. Arrows A and B indicates the full-length fusion protein and the polyhistidine tag, respectively. than the defined cutoff value. The mean absorbance value of the anti- $T$. equi serum group $(1.130 \pm 0.152)$ was approximately 10 times greater than that obtained with non-infected sera, clearly discriminating between mean absorbencies of positive and negative reference sera. Additionally, optical density (OD) readings of $E$. coli crude extract and His6-tagged polypeptide control wells were lower than the defined cut-off value. The EL was determined as shown in Table 1.

\section{Diagnosis of T. equi infection in horses by ELISA with His6-EMA1}

Serum samples collected from 170 field horses in the Northeast region of the State of São Paulo were tested for detection of IgG antibodies to T. equi by ELISA. The number of sera distributed through EL is shown in Figure 4. The estimated ELISA values demonstrated that $95.88 \%$ (163/170) of the horses had EL 3-9, with only $4.12 \%(7 / 170)$ of the serum samples being negative for T. equi infection.

\section{Discussion}

In the present study, we determined the nucleotide sequence of the EMA-1 gene from T. equi Jaboticabal-SP strain, Brazil and comparatively analyzed with other published sequences available in GenBank. The results indicate that even in strains already isolated in Brazil there are sequence differences that are reflected in the derived amino acid sequence. The analysis between T. equi Jaboticabal strain (GenBank accession no. DQ250541) and Pelotas isolate (GenBank accession no. AF255730) showed 99.3\% of identity. Moreover, the analysis of EMA-1 sequences with other strains isolated from various countries reveals differences of as much as $10 \%$ (NICOLAIEWSKY et al., 2001). Previous studies have demonstrated antigenic differences between $T$. equi isolates from various regions (HEUCHERT et al., 1999). Kuttler et al. (1988) obtained higher titers in IFAT test using homologous antigens. Therefore, there is an increasing need to consider differences in parasite characteristics at the molecular level in order to develop more sensitive and specific diagnostic methods. However, Heim et al. (2007) did not find diversity among T. equi isolates obtained from endemic areas of Brazil.

The recombinant antigen was expressed as a histidine-tagged protein in $E$. coli with 35 amino acid residues added at the $\mathrm{N}$-terminus. We investigated the potential use of this protein in ELISA to diagnose T. equi in Brazilian horses. The ELISA proved to be highly specific and sensitive when an $\mathrm{OD}_{405}$ of 0.263 was used as the cutoff titer. The test clearly differentiated between $T$. equiinfected and B. caballi-infected horse sera and healthy horse sera. These results demonstrate that the recombinant EMA-1 expressed in $E$. coli can be a useful diagnostic reagent for the detection of antibodies to $T$. equi, especially in Brazil, when the antigen is produced based on a Brazilian strain. EMA-1 has been proposed as a suitable subunit vaccine or diagnostic antigen for the detection of antibodies to T. equi in horses (KAPPMEYER et al., 1993; KNOWLES et al., 1991). Several ELISA tests for babesiosis using recombinant equi merozoite antigens 1 and 2 produced in $E$. coli or 
Table 1. S/P values for EL 0-9.

\begin{tabular}{cc}
\hline EL & S/P \\
\hline 0 & $0.000-0.131$ \\
1 & $0.132-0.177$ \\
2 & $0.178-0.239$ \\
3 & $0.240-0.323$ \\
4 & $0.324-0.436$ \\
5 & $0.437-0.589$ \\
6 & $0.590-0.795$ \\
7 & $0.796-1.073$ \\
8 & $1.074-1.449$ \\
9 & $\geq 1.450$ \\
\hline
\end{tabular}

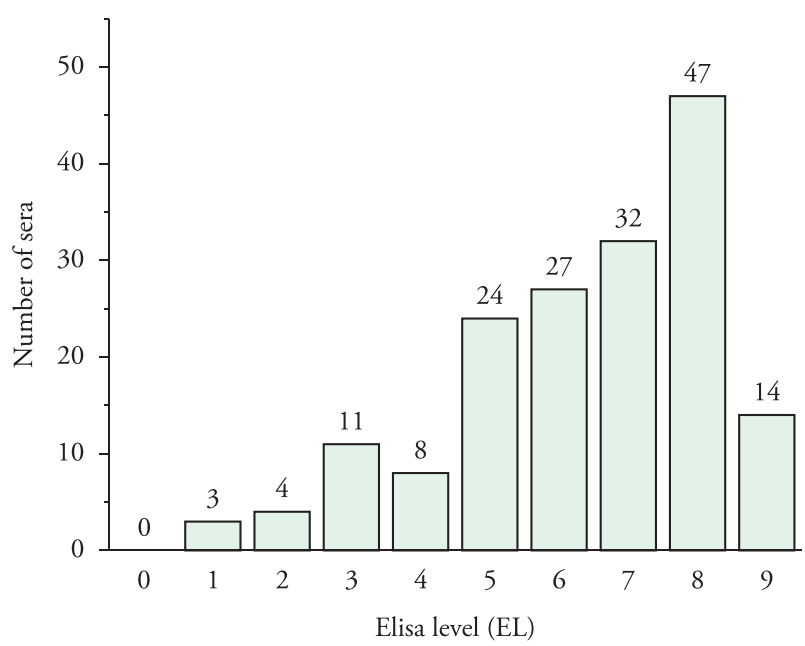

Figure 4. Number of sera from horses $(n=170)$ raised in the Northeast region of the State of Sáo Paulo, Brazil, screened by ELISA using recombinant EMA-1 protein and plotted by ELISA level (EL): 0 (lowest level) to 9 (highest level).

baculovirus insect cell system have been developed (JAFFER et al., 2010; SALIM et al., 2008; HUANG et al., 2003; CUNHA et al., 2002; HIRATA et al., 2002; TANAKA et al., 1999; XUAN et al., $2001 \mathrm{a}, \mathrm{b})$. However, to our best knowledge this is the first report of the development of a recombinant EMA-1 expressed by the gene from $T$. equi Jaboticabal strain.

Additionally, the production of EMA-1 in E. coli as in our study offers some advantages as the methodology is simple and addresses issues of antigen supply or contamination of red blood cell components in antigen preparations (MAHONEY; GOODGER, 1981). As known, protein production in $E$. coli is attractive because high amounts of recombinant protein can be obtained in few hours of induction. Moreover, other advantages include simple protein purification, higher protein yield, improved folding, low proteolysis, simple plasmid construction and economical culture medium.

In this study the recombinant polyhistidine tagged antigen EMA-1 was expressed at high level in a soluble form. Single-step purification by affinity chromatography was sufficient to achieve high amounts of pure protein. However, some native E. coli proteins were copurified during chromatography but these proteins do not exhibit nonspecific reactivity with normal horse sera in ELISA.
Field serum samples collected from horses in the Northeast region of the State of São Paulo were evaluated for the diagnosis of T. equi infection by using ELISA. Of 170 horses tested, $96.5 \%$ were positive and they were all IFAT positive, considering titers equal to or above $1: 80$, as demonstrated in a previous study (BALDANI et al., 2010). Several studies have shown that the prevalence of equine piroplasmosis in Brazil is of serious concern. Heuchert et al. (1999) tested 752 serum samples from the State of São Paulo by IFAT and CFT and reported prevalence rates of $29.6 \%$ and $17.6 \%$, respectively. Serum samples from horses in different regions of Brazil were tested by CTF and the results showed that the prevalence of $T$. equi infection was $42.48 \%$ (KERBER et al., 1999). Xuan et al. (2001b) examined serum samples from horses in the State of São Paulo and Mato Grosso do Sul, central-western Brazil, and found $81 \%$ of T. equi infection. Moreover, Baldani et al. (2004) demonstrated that $75 \%$ of the horses from Sáo Paulo had antibodies anti-T. equi. More recently, Heim et al. (2007) tested horses from endemic areas in Brazil and reported a seroprevalence of $91 \%$ for $T$. equi. The prevalence of equine piroplasmosis reported here is relatively higher and may be due to differences in the serological tests used, horse breeding operations or intensity of tick infestation.

His6-EMA1 strongly reacted with both anti- $T$. equi antibodies produced in mice and sera from $T$. equi-infected horses, as seen in Western blot and dot ELISA analysis, which indicated that the addition of 35 amino acid residues in the N-terminus of full-length EMA-1 did not affect the antigenicity of the protein. Moreover, as in ELISA, His6-EMA1 clearly differentiated T. equi-infected from $B$. caballi infected sera and normal sera.

The results of the present study reinforce the fact that EMA-1 is a suitable candidate for the development of a reliable diagnostic test. ELISA with His6-EMA1 of T. equi expressed in E. coli showed a clear difference between negative and positive reference serum. The antigen did not show cross-reaction with $B$. caballi-infected horse sera and demonstrated to be immunogenic. Moreover, the results indicate that equine babesiosis is widespread and therefore is a serious concern in the State of São Paulo. Further studies should be carried out to investigate the occurrence of equine babesiosis and tick vectors of equine babesiosis in different regions of Brazil using ELISA with recombinant EMA-1 produced from Brazilian strains.

\section{Acknowledgements}

This study was supported by grants from the Conselho Nacional de Pesquisa e Desenvolvimento (CNPq) and Fundação de Amparo a Pesquisa do Estado de São Paulo (FAPESP, 03/12793-3 and 04/05223-9).

\section{References}

BALDANI, C. D. et al. An enzyme-linked immunosorbent assay for the detection of IgG antibodies against Babesia equi in horses. Ciência Rural, v. 34, n. 5, p. 1525-1529, 2004.

BALDANI, C. D.; NAKAGHI, A. C. H.; MACHADO, R. Z. Occurence of Theileria equi in horses raised in the Jaboticabal microregion, São Paulo State, Brazil. Revista Brasileira de Parasitologia Veterinária, v. 19, n. 4, p. 228-232, 2010. 
BRÜNING, A. Equine piroplasmosis an update on diagnosis, treatment and prevention. British Veterinary Journal, v. 152, n. 2, p. 139-151, 1996.

CUNHA, C. W. et al. Conformational dependence and conservation of an immunodominant epitope within the Babesia equi erythrocyte-stage surface protein equi merozoite antigen 1. Clinical and Diagnostic Laboratory Immunology, v. 9, n. 6, p. 1301-1306, 2002.

DE WAAL, D. T. Equine piroplasmosis: a review. British Veterinary Journal, v. 148, n. 1, p. 6-14, 1992.

FRERICHS, W. M.; HOLBROOK, A. A.; JOHNSON, A. J. Equine piroplasmosis complement fixation titers of horses infected with Babesia caballi. American Journal of Veterinary Research, v. 30, n. 5 , p. 697-702, 1969.

GUIMARÁES, A. M.; LIMA, J. D.; RIBEIRO, M. F. B. Sporogony and experimental transmission of Babesia equi by Boophilus microplus. Parasitology Research, v. 84, n. 4, p. 323-327, 1998.

HEIM, A. et al. Detection and molecular characterization of Babesia caballi and Theileria equi isolates from endemic areas of Brazil. Parasitology Research, v. 102, n. 1, p. 63-68, 2007.

HEUCHERT, C. M. et al. Seroepidemiologic studies on Babesia equi and Babesia caballi infections in Brazil. Veterinary Parasitology, v. 85, n. 1, p. 1-11, 1999.

HIRATA, $\mathrm{H}$. et al. Cloning of a truncated Babesia equi gene encoding an 82-kilodalton protein and its potential use in an enzyme-linked immunosorbent assay. Journal of Clinical Microbiology, v. 40, n. 4, p. 1470-1474, 2002.

HUANG, X. et al. High-level expression and purification of a truncated merozoite antigen-2 of Babesia equi in Escherichia coli and its potential for immunodiagnosis. Journal of Clinical Microbiology, v. 41, n. 3, p. $1147-1151,2003$.

JAFFER, O. et al. A comparative study of serological tests and PCR for the diagnosis of equine piroplasmosis. Parasitology Research, v. 106, n. 3, p. 709-713, 2010.

KAPPMEYER, L. S.; PERRYMAN, L. E.; KNOWLES, D. P. A Babesia equi gene encodes a surface protein with homology to Theileria species. Molecular and Biochemical Parasitology, v. 62, n. 1, p. 121-124, 1993.

KERBER, C. E.; FERREIRA, F.; PEREIRA, M. C. Control of equine piroplasmosis in Brazil. Onderstepoort Journal of Veterinary Research, v. 66, n. 2, p. 123-127, 1999.

KNOWLES, D. P. et al. Antibody to a recombinant merozoite protein epitope identifies horses infected with Babesia equi. Journal of Clinical Microbiology, v. 30, n. 12, p. 3122-3126, 1992.

KNOWLES, D. P. et al. Detection of equine antibody to Babesia equi merozoite protein by a monoclonal antibody-based competitive inhibition enzyme-linked immunosorbent assay. Journal of Clinical Microbiology, v. 29, n. 9, p. 2056-2058, 1991.

KNOWLES, D. P.; KAPPMEYER, L. S.; PERRYMAN, L. E. Genetic and biochemical analysis of erythrocyte-stage surface antigens belonging to a family of highly conserved proteins of Babesia equi and Theileria species. Molecular and Biochemical Parasitology, v. 90, n. 1, p. 69-79, 1997.

KUTTLER, K. L. et al. Serologic response of Babesia equi-infected horses as measured by complement-fixation and indirect fluorescent antibody tests. Veterinary Parasitology, v. 26, n. 3-4, p. 199-205, 1988.
LAEMMLI, U. K. Cleavage of structural proteins during the assembly of the head of bacteriophage T4. Nature, v. 227, p. 680-685, 1970

MACHADO, R. Z. et al. Babesia bigemina: isolation and characterization of merozoite rhoptries. Experimental Parasitology, v. 77, n. 3, p. 315-325, 1993.

MAHONEY, D. F.; GOODGER, B. V. The isolation of Babesia parasites and their products from the blood. In: RISTIC, M.; KREIR, J. P. (Ed.). Babesiosis. New York: Academic Press, 1981. p. 323-332.

McGUiRE, T. C.; VAN HOOSIER, G. L.; HENSON, J. B. The complement-fixation reaction in equine infectious anemia: demonstration of inhibition by $\operatorname{IgG}(\mathrm{T})$. Journal of Immunology, v. 107 , n. 6 , p. $1738-1744,1971$.

MONTENEGRO-JAMES, S. et al. Use of the dot enzyme-linked immunosorbent assay with isolated Anaplasma marginale initial bodies for serodiagnosis in cattle. American Journal of Veterinary Research, v. 51, n. 10, p. 1518-1521, 1990.

NICOLAIEWSKY, T. B. et al. Detection of Babesia equi (Laveran, 1901) by nested polymerase chain reaction. Veterinary Parasitology, v. 101, n. 1, p. 9-21, 2001.

RIBEIRO, M. F. B.; COSTA, J. O.; GUIMARÃES, A. M. Epidemiological aspects of Babesia equi in horses in Minas Gerais, Brazil. Veterinary Research Communications, v. 23, n. 6, p. 385-390, 1999.

SALIM, B. O. M. et al. Diagnosis of Babesia caballi and Theileria equi infections in horses in Sudan using ELISA and PCR. Parasitology Research, v. 103, n. 5, p. 1145-1150, 2008.

SCHEIN, E. Equine babesiosis. In: RISTIC, M. (Ed.) Babesiosis of domestic animals and man. Florida: CRS Press, 1988. p. 197-208.

TANAKA, T. et al. Expression of Babesia equi merozoite antigen-2 by recombinant baculovirus and its use in the ELISA. International Journal for Parasitology, v. 29, n. 11, p. 1803-1808, 1999.

TENTER, A. M.; FRIEDHOFF, K. T. Serodiagnosis of experimental and natural Babesia equi and B. caballi infections. Veterinary Parasitology, v. 20, n. $1-3$, p. 49-61, 1986.

TOWBIN, H.; STAEHELIN, T.; GORDON, J. Electrophoretic transfer of proteins from polyacrylamide gels to nitrocellulose sheets: procedure and some applications. Proceedings of the National Academy of Sciences, v. 76, n. 9, p. 4350-4354, 1979.

UETI, M. W. et al. Ability of the vector tick Boophilus microplus to acquire and transmit Babesia equi following feeding on chronically infected horses with low-level parasitemia. Journal of Clinical Microbiology, v. 43, n. 8, p. 3755-3759, 2005.

WEILAND, G. Species-specific serodiagnosis of equine piroplasma infections by means of complement fixation test (CFT), immunofluorescence (IIF), and enzyme-linked immunosorbent assay (ELISA). Veterinary Parasitology, v. 20, n. 1-3, p. 43-48, 1986.

XUAN, X. et al. Expression of Babesia equi merozoite antigen 1 in insect cells by recombinant baculovirus and evaluation of its diagnostic potential in an enzyme-linked immunosorbent assay. Journal of Clinical Microbiology, v. 39, n. 2, p. 705-709, 2001a.

XUAN, X. et al. Diagnosis of equine piroplasmosis in Brazil by serodiagnostic methods with recombinant antigens. Journal of Veterinary Medical Science, v. 63, n. 10, p. 1159-1160, 2001 b. 